Scientia Marina 70 (2)

June 2006, 271-279, Barcelona (Spain)

ISSN: 0214-8358

\title{
Heavy metals in crustaceans from the Iberian deep sea plain
}

\author{
FRIEDERIKE PROWE, MATHIAS KIRF and GERD-PETER ZAUKE
}

Carl von Ossietzky Universität Oldenburg, Institut für Chemie und Biologie des Meeres (ICBM), Postfach 2503, D-26111

Oldenburg, Germany. E-mail: gerd.p.zauke@uni-oldenburg.de

\begin{abstract}
SUMMARY: Trace metals $(\mathrm{Cd}, \mathrm{Cu}, \mathrm{Pb}$ and $\mathrm{Zn})$ were analysed in different well-defined mixed copepod and euphausiid samples as well as in individually analysed decapods collected during a cruise on board "RV Walther Herwig III" to the Iberian Deep Sea Plain in March and April, 2002. We found a substantial interspecific heterogeneity with partially high mean Cd levels in the decapods: $1.9 \mathrm{mg} \mathrm{kg}^{-1}$ dry weight in samples of the genus Sergia; $6.1 \mathrm{mg} \mathrm{kg}^{-1}$ in Acanthephyra pelagica (Risso, 1816) and Acanthephyra acanthithelsonis Bate, $1888 ; 10.7 \mathrm{mg} \mathrm{kg}^{-1}$ in Bentheogennema intermedia (Bate, 1888); $14.9 \mathrm{mg}$ $\mathrm{kg}^{-1}$ in Benthesicymus iridescens (Bate 1881) and $16.3 \mathrm{mg} \mathrm{kg}^{-1}$ in Systellaspis debilis (A. Milne Edwards, 1881). The agreement of these high $\mathrm{Cd}$ concentrations with those reported for polar crustaceans, and Cu concentrations $\left(17-56 \mathrm{mg} \mathrm{kg}^{-1}\right)$ that indicate that the total metabolic requirements have probably not been met, support the hypothesis that the frequently reported Cd-anomaly in polar crustaceans might be extended to other relatively deep ocean waters like the Iberian Deep Sea Plain and that this might be related to a corresponding $\mathrm{Cu}$ deficiency. Zn concentrations in decapods from this study (52-80 mg $\mathrm{kg}^{-1}$ ) are within the worldwide range, which indicates that decapods are able to regulate their Zn body concentrations. Our

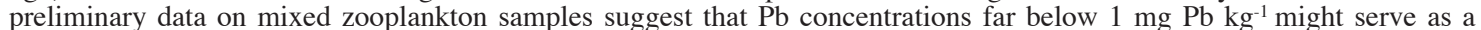
regional background value for comparison in biomonitoring studies. Results for $\mathrm{Cd}, \mathrm{Cu}$ and $\mathrm{Zn}$ are largely within the reported range, especially for data from the Central and Southern North Sea.
\end{abstract}

Keywords: biomonitoring, trace metals, zooplankton, Cd-anomaly, interspecific heterogeneity.

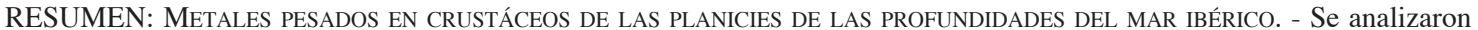
trazas de metales $(\mathrm{Cd}, \mathrm{Cu}, \mathrm{Pb}$ y $\mathrm{Zn}$ ) en diferentes muestras de mezclas bien definidas de Copepoda y Euphausiacea así como en Decapoda, recolectadas en una campaña del crucero "RV Walther Herwig III" en la Llanura Abisal Ibérica durante los meses de marzo y abril del 2002. Se encontró una considerable heterogeneidad interespecífica con algunos niveles promedios altos de Cd en los decápodos: $1,9 \mathrm{mg} \mathrm{kg}^{-1}$ de peso seco en muestras del género Sergia; $6,1 \mathrm{mg} \mathrm{kg}^{-1}$ en Acanthephyra pelágica (Risso, 1816) y en Acanthephyra acanthithelsonis (Bate, 1888); $10,7 \mathrm{mg} \mathrm{kg}^{-1} \mathrm{en}$ Bentheogennema intermedia (Bate, 1888); $14,9 \mathrm{mg} \mathrm{kg}^{-1}$ en Benthesicymus iridescens (Bate, 1881) y $16,3 \mathrm{mg} \mathrm{kg}^{-1}$ en Systellaspis debilis (A. Milne Edwards, 1881). La concordancia de estas altas concentraciones de $\mathrm{Cd}$, con las registradas en crustáceos polares, y las concentraciones de $\mathrm{Cu}\left(17-56 \mathrm{mg} \mathrm{kg}^{-1}\right)$ indican que probablemente no se hayan cumplido todas las necesidades metabólicas. Se soporta la hipótesis que las anomalías de Cd, frecuentemente descritas en crustáceos polares, se podrían extender a otras aguas oceánicas relativamente profundas como la Llanura Abisal Ibérica y que podrían estar relacionadas con la correspondiente deficiencia de $\mathrm{Cu}$. En este estudio, las concentraciones de $\mathrm{Zn}$ en decápodos $\left(52-80 \mathrm{mg} \mathrm{kg}^{-1}\right)$ están dentro del rango mundial lo que indica que los decápodos son capaces de regular su concentración de $\mathrm{Zn}$ corporal. Nuestros datos preliminares obtenidos en muestras de mezclas de zooplancton sugieren que las concentraciones de $\mathrm{Pb}$, muy por debajo de $1 \mathrm{mg} \mathrm{Pb} \mathrm{kg}^{-1}$, podrían servir como valores guía regionales para establecer comparaciones en estudios de biomonitoreo. Los resultados para $\mathrm{Cd}$, $\mathrm{Cu}$ y $\mathrm{Zn}$ están dentro de los rangos publicados, especialmente para las regiones Central y Sur del Mar del Norte.

Palabras claves: biomonitoreo, metales pesados, zooplankton, anomalías de $\mathrm{Cd}$, heterogeneidad interespecífica.

\section{INTRODUCTION}

To assess the environmental quality regarding heavy metals in the oceans, the bioavailable fraction is of great importance, since possible toxic effects are largely dependent on the bioavailable exposure concentration in seawater. This fraction is only accessible by determining the amount of metals 
incorporated in organisms, because this is more dependent on species-specific uptake and detoxification mechanisms and metabolic requirements than on the concentration in the soluble phase ( Rainbow, 1988; Depledge, 1989; Ritterhoff and Zauke, 1998). As a result, we can frequently find different species of zooplankton with greatly varying metal concentrations in the same body of ocean water (Petri and Zauke, 1993; Ritterhoff and Zauke, 1997d; Kahle and Zauke, 2003).

In order to differentiate human impact from natural variability, knowledge of background concentrations of metals and their fluctuations in biomonitor organisms is essential as well as a thorough understanding of accumulation and detoxification strategies. These depend on various aspects, including the biological species and element considered, the applied exposure regime, cation homeostasis mechanisms, life-history status, spatial and temporal scales and other factors (Rainbow and White, 1989; Zauke and Petri, 1993). Studies on crustacean zooplankton from polar regions have revealed particularly high Cd concentrations (Petri and Zauke, 1993; Bargagli et al., 1996; Ritterhoff and Zauke, 1997d), suggesting that probably no global background values can be defined. Instead, regional background values should be established in order to follow possible future trends of metals in biomonitors.

That zooplankton play an important role in the biogeochemical cycling of metals in marine systems in general is well known, especially regarding particle-reactive metals in the water column (e.g. Fowler and Knauer, 1986; Fisher et al., 1991; Lee and Fisher, 1994). Since this was established, several attempts have been made to explicitly use macroand meso-zooplankton organisms as biomonitors for assessing the bioavailability of elements in marine systems, covering a variety of spatial and temporal scales (e.g. Zauke et al., 1996a; Ritterhoff and Zauke, 1997d; Kahle and Zauke, 2003). This is largely due to their worldwide presence, their major role in the food webs and their high contribution to the zooplankton biomass in marine systems.

Classically, studies on metals in biota are related to the species level because this level is implicitly regarded as highly relevant for describing the processes of metal metabolism. This is certainly true in basic physiological studies. For applied studies, however, we propose to select appropriate study units based on a straightforward calibration procedure, involving assessing toxicokinetic parameters
(BCFs, rate constants), clarification of uptake, elimination and storage mechanisms and validation of invariable $\mathrm{BCFs}$ or rate constants under different exposure conditions (see discussions in Phillips and Rainbow, 1989; Rainbow and White, 1989; Petri and Zauke, 1993; Rainbow, 1993; Viarengo and Nott, 1993; Zauke et al., 1995; Zauke et al., 1996b). This calibration may eventually lead to considering levels below the biological species or to welldefined collectives of organisms above the species level (Zauke et al., 1996a).

Recently, an increasing body of information on metals in marine zooplankton has become available for specific regions such as the North Sea, the Nordic Seas and the Antarctic Ocean. In several studies unexpectedly high $\mathrm{Cd}$ concentrations in polar invertebrates were related to effective but unselective uptake mechanisms which had evolved due to potential metabolic deficiencies in $\mathrm{Cu}$ (Petri and Zauke, 1993; Bargagli et al., 1996; Demoreno et al., 1997; Bustamante et al., 1998 ). However, for areas such as the Iberian Deep Sea Plain recent information on metals in zooplankton is largely lacking.

Since early papers reported similarly high Cd concentrations in the decapod Systellaspis debilis from the East Atlantic Ocean (Leatherland et al., 1973; Ridout et al., 1985; Ridout et al., 1989) in comparison to polar regions (see above), we want to provide more detailed information on different decapods from the Iberian Deep Sea Plain to evaluate whether the "Cd-anomaly" is a phenomenon characteristic of polar waters or also common in other deep ocean waters. In addition, mixed meso-zooplankton collectives will be considered as the basis for future biomonitoring assessments, especially in comparison with the North Sea and polar waters.

\section{MATERIALS AND METHODS}

\section{Sampling and sample preparation}

Samples were collected from FRV "Walther Herwig III" (cruise 238, March 15 to April 05, 2002) in two regions of the Iberian Deep Sea Plain at 11 stations (area B $45^{\circ} 50^{\prime} \mathrm{N}, 16^{\circ} 00^{\prime} \mathrm{W}-46^{\circ} 10^{\prime} \mathrm{N}$, $17^{\circ} 30^{\prime} \mathrm{W}$, area East-B $46^{\circ} 00^{\prime} \mathrm{N}, 13^{\circ} 00^{\prime} \mathrm{W}$, see Fig. 1). Zooplankton samples were taken with a vertically towed plankton net (the so called 'Helgoländer Planktonnetz', a net originally used to catch ichthyoplankton, with a mesh size of $500 \mu \mathrm{m}$ and a diam- 


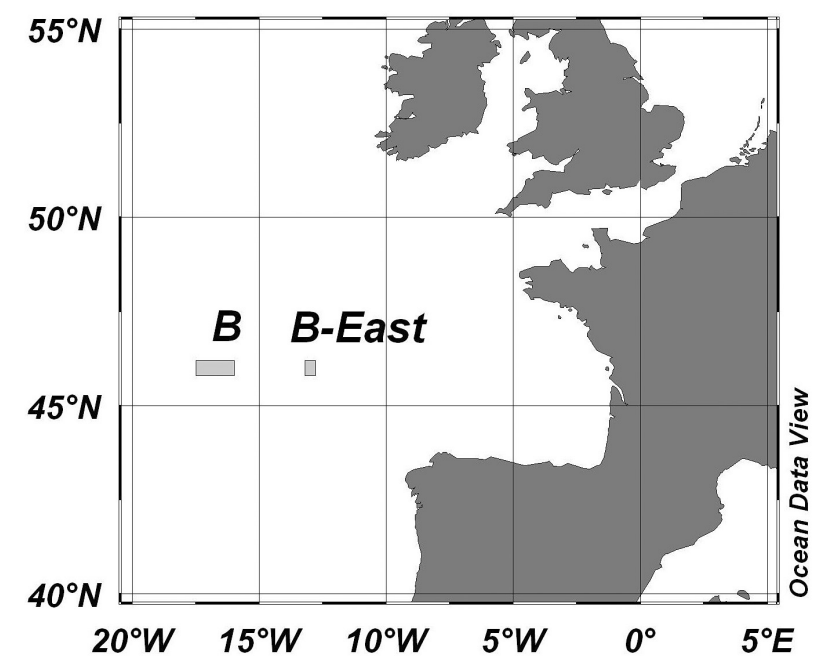

FIG. 1. - Cruise $\mathrm{n}^{\circ} 238$ of the FRV Walther Herwig III (15.0304.04.2002) showing the areas of investigation: B (left) and B-East (right).

eter of $1 \mathrm{~m}$ ) which was hauled at $0.2 \mathrm{~m} \mathrm{sec}^{-1}$ from depths of 100 and $800 \mathrm{~m}$ respectively. Decapod samples originate from catches with an Agassiz trawl (AGT) operated at depths of 4400 to $4800 \mathrm{~m}$ for 4 to $5 \mathrm{~h}$. This trawl was used because the cruise was principally aiming at radio ecological investigations in the marine benthic system. Most probably, many specimens of decapods were caught accidentally at intermediate water depths when hauling the AGT, but more appropriate gear such as the rectangular midwater trawl (RMT) was not available.

On board the ship zooplankton from the 'Helgoländer Planktonnetz' was transferred to polyethylene buckets and kept alive in sea water collected from depths $>500 \mathrm{~m}$ for at least 1 to $3 \mathrm{~h}$ to allow for defecation. We assume complete defecation within this period as gut transit times in copepods are less than $0.5 \mathrm{~h}$ at $18^{\circ} \mathrm{C}$ (Reinfelder and Fisher, 1991). The animals were then sorted, still alive, under a binocular microscope, briefly rinsed with double-distilled water, dried on good-quality filter paper and stored at $-18^{\circ} \mathrm{C}$ in Eppendorf caps (2 ml, polypropylene). In order to meet the minimum requirement of several milligrams dry weight required for further analysis, samples could only be sorted down to a group level (giving samples of small calanoid copepods, larger copepods of the family Euchaetidae and finally Euphausiacea), since more detailed biological assessment procedures were not applicable. This is mainly due to the small size of organisms and the relative species richness, which is comparable to that of the southern North Sea (see Zauke et al., 1996a), but contrasts with polar waters, where sorting of cope- pods and euphausiids down to the species level is no problem (Kahle and Zauke, 2003; Ritterhoff and Zauke, 1997d).

Conversely, decapod samples were largely sorted to species level and further processed as single organisms. Species identification was done by Ludwig Tiefenbacher, Munich, on board ship according to Crosnier and Forest (1973), yielding the following samples: Acanthephyra pelagica (Risso, 1816); Acanthephyra acanthithelsonis Bate, 1888; Systellaspis debilis (A. Milne Edwards, 1881) (Oplophoridae, Caridea); Bentheogennema intermedia (Bate, 1888); Benthesicymus iridescens Bate, 1881 (Penaeidae, Penaeidea); and specimens of the genus Sergia (Sergestes H. Milne Edwards, 1830) (Sergestidae, Penaeidea). The organisms collected were thoroughly rinsed with double-distilled water to remove possible contaminating particles. Superficial water was carefully removed with goodquality filter paper and the animals were stored in Petri dishes or good-quality polyethylene bags at $-18^{\circ} \mathrm{C}$, depending on their size.

To assure the quality of the sampling procedure, we followed the guidelines set up in Zauke et al. (1996a) and Zauke and Petri (1993). The risk of contamination was largely reduced by keeping the animals in sea water or on high-quality filter paper whenever possible.

\section{Analytical procedures}

Upon arrival in the laboratory in Oldenburg, the frozen crustacean samples were subjected to freezedrying for $48 \mathrm{~h}$ to remove remaining water (LYOVAG GT2, Leybold Heraeus). Then the samples were homogenised using a small boron carbide mortar and pestle to avoid losses of biomass. Aliquots of about $10 \mathrm{mg}$ dried material were digested for $3 \mathrm{~h}$ at $80^{\circ} \mathrm{C}$ with $100 \mu 1 \mathrm{HNO}_{3}(65 \%$, suprapure, Merck) in tightly closed 2-ml Eppendorf reaction tubes (Clason and Zauke, 2000). The digests were made up to $2 \mathrm{ml}$ volume with double distilled water.

Metal determinations in biological samples were performed using a Varian SpectrAA 880 Zeeman instrument and a GTA 110 graphite tube atomiser with Zeeman background correction according to Clason and Zauke (2000) and Kahle et al. (2003). Ashing and atomisation temperatures were 600 and $1800^{\circ} \mathrm{C}$ for $\mathrm{Cd}, 1000$ and $2200^{\circ} \mathrm{C}$ for $\mathrm{Pb}, 800$ and $2300^{\circ} \mathrm{C}$ for $\mathrm{Cu}$. For $\mathrm{Cd}$ and $\mathrm{Pb}$, palladium and magnesium nitrate modifiers were applied. $\mathrm{Zn}$ was 
assayed using an air-acetylene flame (SpectrAA-30, deuterium background correction) and a manual micro-injection method (100 $\mu \mathrm{l}$ sample volume). All metal concentrations in biological tissues are reported in $\mathrm{mg} \mathrm{kg}^{-1}\left(\mu \mathrm{g} \mathrm{g}^{-1}\right)$ dry weight (DW).

Quality assurance was performed in line with German GLP regulations (Anonymous, 1999), using the following documented criteria: stability of instrumental recalibration, precision of parallel injections (normally showing a coefficient of variation of 1 to 5 $\%)$ and analytical blanks (also reflecting the digestion procedure). The precision and validity were evaluated using three certified reference materials which were randomly allocated within the determinations (see Table 1). Limits of detection were calculated according to Büttner et al. (1980).

\section{Statistical procedures}

The hypothesis of normal distribution was tested using the Lilliefors test $(\alpha=0.01)$ provided in SYSTAT for Windows (Version 10, Wilkinson, 2000). This program was also used to compute means and 95\% confidence intervals (Wilkinson and Engelman, 2000) of metal concentrations in independent subsamples (viz. bulk samples of meso-zooplankton or specimens of decapods from the different sampling stations, regarded as measurement units). Thus, the experimental unit is the total study area within the Iberian Deep Sea Plain.

Further statistical evaluation was performed with BMDP Dynamics (Release 8.0 for Windows 2000, $\mathrm{XP})$ using one- and two-way analysis of variance with data screening (Dixon, 1992). Firstly, global null hypotheses (equality of means between the taxa investigated) were tested either by classical ANOVA (assuming equality of variances) or by non-classical Welch Test (not assuming equality of variances). The adequate procedure was selected after testing equality of variances using the Levene Test. Null hypotheses were rejected at $95 \%$ significance level $(\mathrm{P}<0.05)$. Secondly, heterogeneity was analysed in more detail using the Student-Newman-Keuls Multiple Range Test (NK) $(\alpha=0.05)$. The robust NK procedure involves an adjusted significance level for each group of ordered means (Dixon, 1992; p. 585). BMDP outputs do not include values for the test statistic but only provide graphical information (that is, means which do not differ significantly are joined to groups by vertical bars). The advantage of this procedure is that results are readily available, in contrast for example to outputs of pairwise t-tests (adjusted to multiple comparisons), which would likewise have been adequate.

\section{RESULTS AND DISCUSSION}

\section{Quality assurance}

The analysed values obtained for reference materials are in most cases in good agreement with the certified values (Table 1), especially regarding lobster hepatopancreas (TORT 2) and mussel tissue (CRM 278). Measured concentrations for cod muscle (CRM 422) are well below our calculated limits of detection, with the sole exception of $\mathrm{Zn}$; the net result is that no relevant contamination has occurred even at low concentrations. Nevertheless, we report the measured values in Table 1 for comparison with the certified values, with the exception of Cd. Limits of detection proved to be adequate for the range of metal concentrations found in this study for marine crustaceans.

\section{Interspecific heterogeneities}

Results for metal concentrations in various crustaceans are shown in Table 2. Values for euphausiids and copepods (mixed calanoid copepods and

TABLE 1. - Quality assurance using certified reference materials randomly allocated within the determinations. Values are means \pm 95\% CI [mg kg-1 DW]. Numbers of independent determinations: ${ }^{\mathrm{a}} 7$; ${ }^{\mathrm{b}} 10 ;{ }^{\mathrm{c}} 11$; ${ }^{\mathrm{d}} 16$; others: 12 ; limits of detection (calculated as 2.6 standard deviations of a "low sample", Büttner et al., 1980): $\mathrm{Cd}=0.12 ; \mathrm{Cu}=1.4 ; \mathrm{Pb}=0.2$ and $\mathrm{Zn}=7\left[\mathrm{mg} \mathrm{kg}^{-1} \mathrm{DW}\right]$.

\begin{tabular}{|c|c|c|c|c|c|c|}
\hline \multirow{2}{*}{. } & \multicolumn{2}{|c|}{$\begin{array}{c}\text { TORT } 2 \\
\text { (lobster hepatopancreas) }\end{array}$} & \multicolumn{2}{|c|}{$\begin{array}{c}\text { CRM } 278 \\
\text { (mussel tissue) }\end{array}$} & \multicolumn{2}{|c|}{$\begin{array}{c}\text { CRM } 422 \\
\text { (Cod muscle) }\end{array}$} \\
\hline & analysed & & analysed & certified & analysed & certified \\
\hline $\mathrm{Cd}$ & $26.2 \pm 1.8$ & $26.7 \pm 0.6$ & $0.287 \pm 0.025^{\mathrm{d}}$ & $0.348 \pm 0.007$ & $<0.12$ & $0.017 \pm 0.002$ \\
\hline $\mathrm{Cu}$ & $97 \pm 4$ & $106 \pm 10$ & $8.63 \pm 0.27$ & $9.45 \pm 0.13$ & $1.08 \pm 0.37^{\mathrm{c}}$ & $1.05 \pm 0.07$ \\
\hline $\mathrm{Pb}$ & $0.32 \pm 0.05$ & $0.35 \pm 0.13$ & $1.89 \pm 0.11$ & $2.00 \pm 0.04$ & $0.102 \pm 0.063^{b}$ & $0.085 \pm 0.015$ \\
\hline $\mathrm{Zn}$ & $175 \pm 20^{b}$ & $180 \pm 5$ & $83.2 \pm 14.4^{b}$ & $83.1 \pm 1.7$ & $13.5 \pm 2.5^{\mathrm{a}}$ & $19.6 \pm 0.5$ \\
\hline
\end{tabular}


TABLE 2. - Trace metal concentrations in crustaceans from the Iberian Deep Sea Plain. Acanthephyra: A. pelagica/ A. acanthithelsonis summarised data; dec = Decapoda; eup = Euphausiacea; cop = Copepoda; $\mathrm{N}$ : number of determinations; LIP: Lilliefors probability $(\alpha=0.01)$; 95\% CI: 95\% confidence intervals; Bars $(\mid)$ indicate homogeneous groups according to the Student-Newman-Keuls Multiple Range Test $(\alpha=0.05)$.

\begin{tabular}{|c|c|c|c|c|c|c|c|c|}
\hline & Collectives & Taxon & $\begin{array}{l}\text { Mean } \pm 95 \% \text { CI } \\
{\left[\mathrm{mg} \mathrm{kg}^{-1} \mathrm{DW}\right]}\end{array}$ & $\mathrm{N}$ & LIP & 1 & $\begin{array}{l}\text { Groups } \\
2\end{array}$ & 3 \\
\hline $\mathrm{Cd}$ & $\begin{array}{l}\text { Euphausiacea } \\
\text { Sergia spec. } \\
\text { Euchaetidae } \\
\text { Acanthephyra spec. } \\
\text { mixed copepods (small) } \\
\text { Bentheogennema intermedia } \\
\text { Benthesicymus iridescens } \\
\text { Systellaspis debilis }\end{array}$ & $\begin{array}{l}\text { eup } \\
\text { dec } \\
\text { cop } \\
\text { dec } \\
\text { cop } \\
\text { dec } \\
\text { dec } \\
\text { dec }\end{array}$ & $\begin{array}{c}0.8 \pm 0.1 \\
1.9 \pm 0.8 \\
3.8 \pm 0.6 \\
6.1 \pm 3.2 \\
6.3 \pm 0.6 \\
10.7 \pm 6.7 \\
14.9 \pm 10.9 \\
16.3 \pm 4.6\end{array}$ & $\begin{array}{l}10 \\
8 \\
7 \\
6 \\
11 \\
9 \\
7 \\
12\end{array}$ & $\begin{array}{l}0.053 \\
0.738 \\
1.000 \\
0.982 \\
0.827 \\
0.012 \\
0.359 \\
1.000\end{array}$ & & & \\
\hline $\mathrm{Cu}$ & $\begin{array}{l}\text { Euchaetidae } \\
\text { mixed copepods (small) } \\
\text { Sergia spec. } \\
\text { Euphausiacea } \\
\text { Bentheogennema intermedia } \\
\text { Systellaspis debilis } \\
\text { Benthesicymus iridescens } \\
\text { Acanthephyra spec. }\end{array}$ & $\begin{array}{l}\text { cop } \\
\text { cop } \\
\text { dec } \\
\text { eup } \\
\text { dec } \\
\text { dec } \\
\text { dec } \\
\text { dec }\end{array}$ & $\begin{array}{l}10 \pm 4 \\
11 \pm 3 \\
17 \pm 7 \\
25 \pm 9 \\
36 \pm 36 \\
49 \pm 13 \\
55 \pm 46 \\
56 \pm 29\end{array}$ & $\begin{array}{l}7 \\
11 \\
8 \\
10 \\
9 \\
12 \\
7 \\
6\end{array}$ & $\begin{array}{l}0.173 \\
0.037 \\
1.000 \\
0.067 \\
0.005 \\
0.475 \\
0.062 \\
0.773\end{array}$ & & & \\
\hline $\mathrm{Pb}$ & $\begin{array}{l}\text { Euchaetidae } \\
\text { Euphausiacea } \\
\text { Benthesicymus iridescens } \\
\text { Bentheogennema intermedia } \\
\text { Sergia spec. } \\
\text { Systellaspis debilis } \\
\text { Acanthephyra spec. } \\
\text { mixed copepods (small) }\end{array}$ & $\begin{array}{l}\text { cop } \\
\text { eup } \\
\text { dec } \\
\text { dec } \\
\text { dec } \\
\text { dec } \\
\text { dec } \\
\text { cop }\end{array}$ & $\begin{array}{l}0.2 \pm 0.2 \\
0.3 \pm 0.2 \\
0.4 \pm 0.3 \\
0.4 \pm 0.3 \\
0.5 \pm 0.3 \\
0.6 \pm 0.2 \\
0.6 \pm 0.6 \\
0.8 \pm 0.3\end{array}$ & $\begin{array}{l}7 \\
10 \\
7 \\
9 \\
8 \\
13 \\
7 \\
10\end{array}$ & $\begin{array}{l}0.379 \\
0.001 \\
0.244 \\
0.002 \\
0.064 \\
0.281 \\
0.199 \\
0.376\end{array}$ & & & \\
\hline $\mathrm{Zn}$ & $\begin{array}{l}\text { Acanthephyra spec. } \\
\text { Systellaspis debilis } \\
\text { Sergia spec. } \\
\text { Euphausiacea } \\
\text { Bentheogennema intermedia } \\
\text { Benthesicymus iridescens } \\
\text { Euchaetidae } \\
\text { mixed copepods (small) }\end{array}$ & $\begin{array}{l}\text { dec } \\
\text { dec } \\
\text { dec } \\
\text { eup } \\
\text { dec } \\
\text { dec } \\
\text { cop } \\
\text { cop }\end{array}$ & $\begin{array}{l}52 \pm 9 \\
62 \pm 9 \\
67 \pm 12 \\
72 \pm 22 \\
74 \pm 16 \\
79 \pm 19 \\
160 \pm 113 \\
234 \pm 46\end{array}$ & $\begin{array}{l}7 \\
13 \\
8 \\
10 \\
9 \\
7 \\
7 \\
10\end{array}$ & $\begin{array}{l}1.000 \\
0.000 \\
0.015 \\
1.000 \\
0.465 \\
1.000 \\
0.223 \\
0.051\end{array}$ & & & \\
\hline
\end{tabular}

Euchaetidae, larger than $2 \mathrm{~mm}$ ) represent mixed collectives and, in the case of the decapods, single organisms. The null hypothesis assuming normal distribution did not have to be rejected in most cases according to the Lilliefors probabilities (LIP). The global null hypotheses (equality of means between the different collectives analysed) had to be rejected for $\mathrm{Cd}, \mathrm{Cu}$ and $\mathrm{Zn}$ due to the results of the Welch or $\mathrm{F}$ statistics, but not for $\mathrm{Pb}$ (Table 3). Subsequent analyses with the Student-Newman-Keuls Multiple Range Test revealed different groups for $\mathrm{Cd}$ and $\mathrm{Zn}$ but not for $\mathrm{Cu}$ and $\mathrm{Pb}$ (Table 2).

The highest concentrations of $\mathrm{Cd}$ were found for the decapods Bentheogennema intermedia, Benthesicymus iridescens and Systellaspis debilis (group 3) and the lowest concentrations (group 1) for euphausiids, both collectives of copepods and the decapods Sergia spec. and Acanthephyra pelagica / A. acanthithelsonis, for which results were pooled due to their rare occurrence.
TABLE 3. - Trace metal concentrations in crustaceans from the Iberian Deep Sea Plain: Test of global null hypotheses. LS: Levene statistic; WS: Welch statistic; F: F-value (ANOVA); P: tail probability (corresponding null hypotheses are rejected when $\mathrm{P}<0.05$ ); df: degrees of freedom (for LS = strata-1; total of determinations-strata).

\begin{tabular}{ccccccc}
\hline & LS & P & \multicolumn{2}{c}{ ANOVA } & P & df \\
\hline $\mathrm{Cd}$ & 13.2 & 0.000 & WS & 75.1 & 0.000 & 7,22 \\
$\mathrm{Cu}$ & 8.1 & 0.000 & WS & 8.9 & 0.000 & 7,24 \\
$\mathrm{~Pb}$ & 1.1 & 0.398 & $\mathrm{~F}$ & 2.2 & 0.050 & 7,63 \\
$\mathrm{Zn}$ & 14.3 & 0.000 & WS & 11.3 & 0.000 & 7,25 \\
\hline
\end{tabular}

However, we found a substantial overlap of the NK groups, most probably due to the large intraspecific heterogeneities in the decapods. A fine separation of groups was also detected by the NK procedure for $\mathrm{Zn}$ with the highest values in both copepod collectives (group 2) and the lower values in the euphausiids and the decapods (group 1). For $\mathrm{Cu}$ and $\mathrm{Cd}$ no further interspecific hetero- 
geneity could be discerned: regarding $\mathrm{Pb}$, due to the generally low concentrations close to the limit of detection and regarding $\mathrm{Cu}$, most probably due to the large intraspecific heterogeneity in the decapods analysed.

The large confidence intervals obtained for the decapod samples not only reflect a high natural variability of single organisms but may also be caused by the bad state of many animals caught with the AGT. Since many trace metals are stored in detoxified form in certain organs like the hepatopancreas of decapods (Viarengo and Nott, 1993), damage to the relevant body part can result in decreasing and varying whole-body concentrations. However, since better material could not be collected during this cruise, we regarded this circumstance as acceptable in order to evaluate one of our main hypotheses regarding the Cd-anomaly (see below). Furthermore, determinations relying on single organisms, as in the case of decapod samples, are influenced by the high natural variability of metals in individual organisms due to varying life-history stages (such as body length) or the sex of the individuals ( Rainbow, 1988; Ridout et al., 1989; Zauke and Petri, 1993; Ritterhoff and Zauke, 1997c).

An a posteriori quality control of sample collection according to Zauke and Petri (1993) can be inferred from our results compiled in Table 2. A successful quality control of the analytical procedure (see previous section) is probably not the most crucial feature in determining metal concentrations in organisms from remote areas. In contrast to the widely accepted concept of "good laboratory practice", there are no straightforward protocols available for quality control of sampling and sample preparation on board ship. Therefore we can only present arguments based more or less on plausibility. Regarding individual organisms collected on one particular cruise, it is very likely that a possible contamination would affect all samples (e.g. due to contaminated water or dust or equipment), or some individual organisms (not species or measurement units) by chance, e.g. due to residues of paints or grease. $\mathrm{Pb}$ concentrations close to the limit of detection in almost all cases, as well as the pronounced interspecific heterogeneity found for Cd (starting at low concentrations in euphausiids), demonstrate that on board contamination was very unlikely in this study, as in previous investigations (Petri and Zauke, 1993; Zauke et al., 1996a; Ritterhoff and Zauke, 1997d).

\section{Hypothesis of a Cd-anomaly and $\mathrm{Cu}$-deficiency inferred from literature data}

Heavy-metal concentrations in various marine pelagic crustaceans and in zooplankton reported in the literature are compiled in Table 4. High Cd concentrations found in this study (Table 2) for Systellaspis debilis are in good agreement with data reported for the same species from the North East Atlantic ranging from 5.7 to $32 \mathrm{mg} \mathrm{Cd} \mathrm{kg}^{-1}$. Conversely, our values found for Acanthephyra pelagica and A. acanthithelsonis which show similar metal concentrations, clearly exceed the ranges reported for Acanthephyra exima and A. purpurea.

Our results for $\mathrm{Cd}$ in decapods coincide with the $\mathrm{Cd}$-anomaly reported for many invertebrates from polar waters, which has been intensively discussed in the literature (Petri and Zauke, 1993; Zauke and Petri, 1993; Bargagli et al., 1996; Demoreno et al., 1997; Ritterhoff and Zauke, 1997d; Bustamante et $a l ., 1998)$. Since these regions are considered to be rather isolated, high $\mathrm{Cd}$ concentrations in Antarctic crustaceans have not been related to anthropogenic influences but are regarded as indications of a $\mathrm{Cu}$ deficiency (Petri and Zauke, 1993; Zauke and Petri, 1993). It has been hypothesised that a potential copper deficiency might be related to an increased uptake of $\mathrm{Cd}$ due to insufficient selectivity of the uptake process for the essential element $\mathrm{Cu}$. Theoretical considerations have suggested metabolic requirements for decapods from temperate waters with about 7 to $15 \mathrm{mg} \mathrm{kg}^{-1}$ of $\mathrm{Cu}$ being sufficient for enzymatic requirements and 30 to $40 \mathrm{mg} \mathrm{kg}^{-1}$ meeting the total metabolic (enzymatic and haemocyanin component) demand (Rainbow, 1993). Thus, some of the decapod species analysed from polar regions (Table 4), and even more those from the Iberian Deep Sea Plain (Table 2), might be suffering $\mathrm{Cu}$ deficiencies in the sense that their total metabolic requirements have probably not been met.

$\mathrm{Zn}$ concentrations in decapods of this study (Table 2) are within the range reported for comparable organisms in the literature (Table 4). These results support the conclusion of Rainbow and White (1989) that decapods are able to regulate their $\mathrm{Zn}$ body concentrations, probably leading to wholebody concentrations that are comparable worldwide. $\mathrm{Pb}$ in decapods is generally low, mostly below $1 \mathrm{mg}$ $\mathrm{kg}^{-1}$ and at times close to the limit of detection.

Our results for mixed copepods and copepods of the family Euchaetidae are largely within the report- 
TABLE 4. - Trace metal concentrations for different regions of the world $\left[\mathrm{mg} \mathrm{kg}^{-1} \mathrm{~d} . \mathrm{w}.\right]$ : taxa: dec $=$ Decapoda; amp = Amphipoda; eup $=$ Euphausiacea; cop = Copepoda. References: 1: Ridout et al. (1985); 2: Leatherland et al. (1973); 3: White and Rainbow (1987); 4: Ridout et al. (1989); 5: Zauke and Schmalenbach (2006); 6: Zauke et al. (1996a); 7: Witzel (1989); 8: Martin and Knauer (1973); 9: Bohn and McElroy (1976); 10: Ritterhoff and Zauke (1997d); 11: Rainbow and White (1989); 12: Petri and Zauke (1993); 13: Kahle and Zauke (2003).

\begin{tabular}{|c|c|c|c|c|c|c|c|}
\hline Species & Taxon & Region & $\mathrm{Cd}$ & $\mathrm{Cu}$ & $\mathrm{Pb}$ & $\mathrm{Zn}$ & Ref \\
\hline Systellaspis debilis & dec & Atlantic, African Coast & $11-32$ & $26-83$ & & $42-93$ & 1 \\
\hline Systellaspis debilis & dec & Atlantic, Azores Islands & 13 & & & 50 & 2 \\
\hline Systellaspis debilis & dec & N.E. Atlantic Ocean & $5.7-18$ & $21-112$ & & $41-65$ & 3 \\
\hline Systellaspis debilis & dec & N.E. Atlantic Ocean & $8.7-13$ & $49-66$ & & $35-47$ & 4 \\
\hline Acanthephyra exima & dec & Atlantic, Azores Islands & 3.0 & & & & 2 \\
\hline Acanthephyra purpurea & dec & N.E. Atlantic Ocean & $2.1-3.8$ & $29-43$ & & $38-57$ & 4 \\
\hline Pandalus borealis & dec & Barents Sea & 1.6 & 61 & 1.0 & 79 & 5 \\
\hline Hymenodora glacialis & dec & Greenland Sea & 6.7 & 16 & $<0.3$ & 37 & 10 \\
\hline Chorismus antarcticus & dec & Weddell Sea & 13.3 & 93 & 1.6 & 44 & 12 \\
\hline Notocrangon antarcticus & dec & Weddell Sea & 13.4 & 67 & 0.8 & 46 & 12 \\
\hline euphausiids & eup & Central North Sea & 0.18 & 28 & 0.7 & 70 & 6 \\
\hline Euphausia superba & eup & Weddell Sea & 3.5 & 66 & 0.3 & 33 & 12 \\
\hline Meganyctiphanes norvegica & eup & Greenland Sea & 0.44 & 35 & $<0.3$ & 42 & 10 \\
\hline Meganyctiphanes norvegica & eup & Barents Sea & 0.16 & 47 & - & 73 & 5 \\
\hline mixed copepods & cop & German Bight & 0.9 & 8.4 & 1.0 & 323 & 6 \\
\hline mixed copepods & cop & Central North Sea & 1.9 & 22 & 2.4 & 474 & 6 \\
\hline mixed copepods & cop & German Bight & 2.0 & 8.6 & 2.7 & & 7 \\
\hline mixed copepods & cop & Monterey (CA, USA) & 4.3 & 13 & 3.6 & 116 & 8 \\
\hline mixed copepods & cop & Baffin Island (Canada) & 3.9 & 3.5 & & 67 & 9 \\
\hline copepods $^{1}$ & cop & Barents Sea & $2.4-6.3$ & $6-9$ & $<0.3$ & $108-509$ & 5 \\
\hline copepods $^{1}$ & cop & Greenland Sea & $0.3-0.6$ & $4-6$ & $0.3-0.5$ & $86-390$ & 10 \\
\hline copepods $^{2}$ & cop & Weddell Sea & $3.7-10.2$ & $11-26$ & $0.2-0.7$ & $183-518$ & 13 \\
\hline Hyperia spec & amp & Northern North Sea & 51 & 26 & 1.8 & 72 & 6 \\
\hline Themisto abyssorum & amp & Barents Sea & 10.5 & 9.1 & 0.8 & 110 & 5 \\
\hline Themisto abyssorum & amp & Greenland Sea & 28.2 & 23.5 & 1.0 & 92 & 10 \\
\hline Themisto libellula & amp & Greenland Sea & 33.8 & 26.2 & 0.4 & 61 & 10 \\
\hline Themisto compressa & amp & NE Atlantic & 70 & & & & 11 \\
\hline
\end{tabular}

${ }^{1}$ summarised data for Calanus hyperboreus, Calanus finmarchicus, Metridia longa

${ }^{1}$ summarised data for Rhincalanus gigas, Calanus propinquus, Calanoides acutus, Metridia gerlachei.

ed range for $\mathrm{Cd}, \mathrm{Cu}$ and $\mathrm{Zn}$, especially where data from the Central and Southern North Sea are concerned. Only Cd concentrations reported from the Weddell Sea (Table 4) and from the Northern North Sea (11 $\mathrm{mg} \mathrm{kg}^{-1}$; Zauke et al., 1996a) are distinctly higher. The latter were attributed to upwelling phenomena in this region. For $\mathrm{Pb}$, we found distinctly lower concentrations in copepods from the Iberian Deep Sea Plain, probably indicating some regional background value. This idea is supported by the following arguments: $\mathrm{Pb}$ mainly enters the marine system by atmospheric deposition, so that the $\mathrm{Pb}$ concentration in the soluble phase is highest in the euphotic zone, decreasing with increasing depths, in contrast to other trace metals, where depth distributions are closely related to those of nutrients. This is the reason for increased $\mathrm{Cd}$ availabilities in upwelling areas (see above). Moreover, $\mathrm{Pb}$ concentrations in seawater were found to be higher in parts of the North Sea surrounded by highly industrialised areas (40-60 ng 1-1. OSPAR Commission, 2000b) compared to the open Atlantic (5-20 ng 1 $^{-1}$, OSPAR Commission, 2000c) with predominant west winds coming from the west Atlantic, or compared to the rather isolated Arctic Ocean (4-15 $\mathrm{ng} \mathrm{l}^{-1}$, OSPAR Commission, 2000a). This might account for observed regional differences of $\mathrm{Pb}$ in copepods and perhaps in decapods.

Even if $\mathrm{Cu}$ requirements for copepods are considered to be similar to those of decapods (which has to be proven in future studies) they must be lower, because copepods, and also some hyperiid amphipods like Themisto, lack haemocyanin (Gruner et al., 1993). This might also help to explain the observed low $\mathrm{Cu}$ concentrations in copepods as opposed to decapods.

Our data for euphausiids in the Iberian Deep Sea Plain (Table 2) are largely within the reported range for $\mathrm{Cu}, \mathrm{Pb}$ and $\mathrm{Zn}$. Only for $\mathrm{Cd}$ do we find somewhat increased values compared to northern waters, but much lower ones compared to the Weddell Sea (Table 4). Only limited information is available from our study on pelagic amphipods of the Iberian Deep Sea Plain, namely the ranges 4.1 to $31.0 \mathrm{mg}$ $\mathrm{Cd} \mathrm{kg}^{-1} ; 4$ to $17 \mathrm{mg} \mathrm{Cu} \mathrm{kg}^{-1} ; 1.0$ to $2.6 \mathrm{mg} \mathrm{Pb} \mathrm{kg}^{-1}$ and 26 to $260 \mathrm{mg} \mathrm{Zn} \mathrm{kg}^{-1}$. These values are again within the reported range for other pelagic amphipods (Table 4). These observations probably 
indicate a more general occurrence of accumulation strategies (see arguments given above for decapods) - especially for $\mathrm{Cd}$, for which efficient detoxification mechanisms have been described for Themisto libellula and Themisto abyssorum from the Greenland sea, suggesting that Cd-binding proteins like metallothionein may play a major role in this process (Ritterhoff and Zauke, 1998).

Despite the large intraspecific variability observed for individually analysed decapods, our study provides further evidence that the frequently reported $\mathrm{Cd}$-anomaly in polar crustaceans might be extended to other deeper ocean waters like the Iberian Deep Sea Plain and that this might be related to a corresponding $\mathrm{Cu}$ deficiency. This could be the consequence of efficient uptake mechanisms for $\mathrm{Cu}$ which cannot discriminate between the two elements. To test this hypothesis, further experimental studies are required, investigating in more detail, for example, the role of metal-binding proteins in this process. Our preliminary data on mixed zooplankton samples suggest that $\mathrm{Pb}$ concentrations below $1 \mathrm{mg}$ $\mathrm{Pb} \mathrm{kg}^{-1}$ might serve as a regional background value for comparison in biomonitoring studies. This should be further evaluated by toxicokinetic bioaccumulation studies on board ship as previously reported for polar waters (Ritterhoff and Zauke, 1997a, 1997b; Kahle and Zauke, 2002a, 2002b).

\section{ACKNOWLEDGEMENTS}

We thank the captain and crew of the RV Walther Herwig III as well as the Bundesforschungsanstalt für Fischerei, Hamburg for their kind cooperation during the cruise to the Iberian Deep Sea Plain and for providing Figure 1. The help of Dr. Ludwig Tiefenbacher, ZSM, Munich, in identifying the decapods and of Kristine Jung and Edith Kieselhorst in the metal determination is gratefully acknowledged. Part of the experimental work was done by F.P. and M.K. during student courses in Marine Environmental Sciences at the University of Oldenburg.

\section{REFERENCES}

Anonymous. - 1999. Chemikaliengesetz: Gesetz zum Schutz vor gefährlichen Stoffen. Anhang 1 (zu § 19a Abs. 1) - Grundsätze der guten Laborpraxis (GLP). In: C. Steinberg, H. Bernhardt, W. Calmano, H. Klapper and R.-D. Wilken (eds.), Handbuch angewandte Limnologie, Chapter IX-5, 7. Erg. Lfg. 4/99. ecomed, Landsberg am Lech.

Bargagli, R., L. Nelli, S. Ancora and S. Focardi. - 1996. Elevated cadmium accumulation in marine organisms from Terra Nova Bay (Antarctica). Polar Biol., 16: 513-520.

Bohn, A. and R.O. McElroy. - 1976. Trace metals (As, Cd, Cu, Fe and $\mathrm{Zn}$ ) in Arctic cod, Boreogadus saida and selected zooplankton from Strathcona Sound, North Baffin Island. J. Fish. Res. Board Can., 33: 2836-2840.

Bustamante, P., Y. Cherel, F. Caurant and P. Miramand. - 1998. Cadmium, copper and zinc in octopuses from Kerguelen Islands, Southern Indian Ocean. Polar Biol., 19: 264-271.

Büttner, J.R., R. Borth, H.J. Boutwell, P.M.G. Broughton and R.C. Bowyer. - 1980. Approved recommendation (1978) on quality control in clinical chemistry. J. Clin. Chem. Clin. Biochem., 18 78-88.

Clason, B. and G.-P. Zauke. - 2000. Bioaccumulation of trace metals in marine and estuarine amphipods: evaluation and verification of toxicokinetic models. Can. J. Fish. Aquat. Sci., 57: $1410-1422$

Crosnier, A. and J. Forest. - 1973. Les crevettes profondes de l'Atlantique oriental tropical, Faune Tropical XIX. Office de la Recherche Scientifique et Technique Outre-Mer, Paris, 19: 1-409.

Demoreno, J.E.A., M.S. Gerpe, V.J. Moreno and C. Vodopivez.1997. Heavy metals in Antarctic organisms. Polar Biol., 17: 131-140.

Depledge, M.H. - 1989. Re-evaluation of metabolic requirements for copper and zinc in decapod crustaceans. Mar. Environ. Res., 27: 115-126.

Dixon, W.J. ed. - 1992. BMDP statistical software manual (version 7.0), Volume 1. University Press of California, Berkeley, CA, USA.

Fisher, N.S., C.V. Nolan and S.W. Fowler. - 1991. Assimilation of metals in marine copepods and its biogeochemical implications. Mar. Ecol. Prog. Ser., 71: 37-43.

Fowler, S.W. and G.A. Knauer. - 1986. Role of large particles in the transport of elements and organic compounds through the oceanic water column. Prog. Oceanogr., 16: 147-194.

Gruner, H.-E., M. Moritz and W. Dunger. - 1993. Lehrbuch der speziellen Zoologie (begr. von A. Kaestner), Wirbellose Tiere, 4. Teil: Arthropoda (ohne Insecta). Gustav Fischer, Stuttgart.

Kahle, J., B. Clason and G.-P. Zauke. - 2003. Sequential determination of $\mathrm{Cd}, \mathrm{Cu}, \mathrm{Pb}, \mathrm{Co}$ and $\mathrm{Ni}$ in marine invertebrates by graphite furnace atomic absorption spectroscopy and Zeeman background correction. Varian AA at Work No. 129: 1-15.

Kahle, J. and G.-P. Zauke. - 2002a. Bioaccumulation of trace metals in the calanoid copepod Metridia gerlachei from the Weddell Sea (Antarctica). Sci. Total Environ., 295: 1-16.

Kahle, J. and G.-P. Zauke. - 2002b. Bioaccumulation of trace metals in the copepod Calanoides acutus from the Weddell Sea (Antarctica): comparison of two-compartment and hyperbolic toxicokinetic models. Aquat. Toxicol., 59: 115-135.

Kahle, J. and G.-P. Zauke. - 2003. Trace metals in Antarctic copepods from the Weddell Sea (Antarctica). Chemosphere, 51: 409-417.

Leatherland, T.M., J.D. Burton, F. Culkin, M.J. McCartney and R.J. Morris. - 1973. Concentrations of some trace metals in pelagic organisms and of mercury in Northeast Atlantic Ocean water. Deep Sea Res., 20: 679-685.

Lee, B.-G. and N.S. Fisher. - 1994. Effects of sinking and zooplankton grazing on the release of elements from planktonic debris. Mar. Ecol. Prog. Ser., 110: 271-281.

Martin, J.H. and G.A. Knauer. - 1973. The elemental composition of plankton. Geochim. Cosmochim. Acta, 37: 1639-1653.

OSPAR Commission. - 2000a. Quality Status Report 2000, Region I - Arctic Waters pp. 102. OSPAR Commission, London.

OSPAR Commission. - 2000b. Quality Status Report 2000, Region II - Greater North Sea pp. 136. OSPAR Commission, London.

OSPAR Commission. - 2000c. Quality Status Report 2000, Region V - Wider Atlantic pp. 110. OSPAR Commission, London.

Petri, G. and G.-P. Zauke. - 1993. Trace-Metals in Crustaceans in the Antarctic Ocean. Ambio, 22: 529-536.

Phillips, D.J.H. and P.S. Rainbow. - 1989. Strategies of trace metal sequestration in aquatic organisms. Mar. Environ. Res., 28: 207-210.

Rainbow, P.S. - 1988. The significance of trace metal concentrations in decapods. Zool. Soc. Lond. Zool. Symp., 59: 291-313.

Rainbow, P.S. -1993 . The significance of trace metal concentration 
in marine invertebrates. In: R. Dallinger and P.S. Rainbow (eds.), Ecotoxicology of metals in invertebrates., pp. 4-23. Lewis Publishers, Boca Raton, USA.

Rainbow, P.S. and S.L. White. - 1989. Comparative strategies of heavy metal accumulation by crustaceans: Zinc, copper and cadmium in a decapod, an amphipod and a barnacle. Hydrobiologia, 174: 245-262.

Reinfelder, J.R. and N.S. Fisher. - 1991. The assimilation of elements ingested by marine copepods. Science, 251: 794-796.

Ridout, P.S., P.S. Rainbow, H.S.J. Roe and H.R. Jones. - 1989. Concentrations of $\mathrm{V}, \mathrm{Cr}, \mathrm{Mn}, \mathrm{Fe}, \mathrm{Ni}, \mathrm{Co}, \mathrm{Cu}, \mathrm{Zn}, \mathrm{As}$ and $\mathrm{Cd}$ in mesopelagic curstaceans from the North East Atlantic Ocean. Mar. Biol., 100: 465-471.

Ridout, P.S., A.D. Willcocks, R.J. Morris, S.L. White and P.S. Rainbow. - 1985. Concentrations of $\mathrm{Mn}, \mathrm{Fe}, \mathrm{Cu}, \mathrm{Zn}$ and $\mathrm{Cd}$ in the mesopelagic decapod Systellaspis debilis from the East Atlantic Ocean. Mar. Biol., 87: 285-288.

Ritterhoff, J. and G.-P. Zauke. - 1997a. Bioaccumulation of trace metals in Greenland Sea copepod and amphipod collectives on board ship: verification of toxicokinetic model parameters Aquat. Toxicol., 40: 63-78.

Ritterhoff, J. and G.-P. Zauke. - 1997b. Evaluation of trace metal toxicokinetics in Greenland Sea copepod and amphipod collectives from semi-static experiments on board ship. Polar Biol., 17: $242-250$

Ritterhoff, J. and G.-P. Zauke. - 1997c. Influence of body length, life-history status and sex on trace metal concentrations in selected zooplankton collectives from the Greenland Sea. Mar. Pollut. Bull., 34: 614-621.

Ritterhoff, J. and G.-P. Zauke - 1997d. Trace metals in field samples of zooplankton from the Fram Strait and the Greenland Sea. Sci. Total Environ., 199: 255-270.

Ritterhoff, J. and G.-P. Zauke. - 1998. Potential role of metal-binding proteins in cadmium detoxification in Themisto libellula (Mandt) and Themisto abyssorum Boeck from the Greenland sea. Mar. Environ. Res., 45: 179-191.

Viarengo, A. and J.A. Nott. - 1993. Mini-review. Mechanisms of heavy metal cation homeostasis in marine invertebrates. Comp. Biochem. Physiol., 104C: 355-372.
White, S.L. and P.S. Rainbow. - 1985. On the metabolic requirements for copper and zinc in molluscs and crustaceans. Mar. Environ. Res., 16: 215-229.

White, S.L. and P.S. Rainbow. - 1987. Heavy metal concentrations and size effects in the mesopelagic decapod crustacean Systellaspis debilis. Mar. Ecol. Prog. Ser., 37: 147-151.

Wilkinson, L. - 2000. Nonparametric statistics. In: Anonymous (eds.), SYSTAT 10: Statistics II, pp. 197-218. SPSS Inc, Chicago, IL.

Wilkinson, L. and L. Engelman. - 2000. Descriptive statistics. In: Anonymous (eds.), SYSTAT 10: Statistics I, pp. 205-225. SPSS Inc, Chicago, IL.

Witzel, B. - 1989. Schwermetallkonzentrationen in Copepoden aus verschiedenen Wassermassen der Deutschen Bucht. Z. Angew. Zool., 3: 303-332.

Zauke, G.-P., M. Krause and A. Weber. - 1996a. Trace metals in mesozooplankton of the North Sea: Concentrations in different taxa and preliminary results on bioaccumulation in copepod collectives (Calanus finmarchicus / C. helgolandicus). Int. Revue Ges. Hydrobiol., 81: 141-160.

Zauke, G.-P. and G. Petri. - 1993. Metal concentrations in Antarctic Crustacea. The problem of background levels. In: R. Dallinger and P.S. Rainbow (eds.), Ecotoxicology of metals in invertebrates, pp. 73-101. Lewis Publishers, Boca Raton, USA.

Zauke, G.-P., G. Petri, J. Ritterhoff and H.-G. Meurs. - $1996 \mathrm{~b}$. Theoretical background for the assessment of the quality status of ecosystems: lessons from studies of heavy metals in aquatic invertebrates. Senckenbergiana marit., 27: 207-214.

Zauke, G.P., R. Von Lemm, H.G. Meurs and W. Butte. - 1995. Validation of Estuarine Gammarid Collectives (Amphipoda, Crustacea) as Biomonitors for Cadmium in Semi-Controlled Toxicokinetic Flow-through Experiments. Environ. Pollut., 90: 209-219.

Zauke, G.-P. and I. Schmalenbach. - 2006. Heavy metals in zooplankton and decapod crustaceans from the Barents Sea. Sci. Total Environ., 359: 283-294.

Scient. ed.: F. Sardà

Received March 18, 2005. Accepted September 26, 2005. 
